\title{
Measuring real exchange rate misalignment in Croatia: cointegration approach
}

\author{
Irena Palić ${ }^{1, *}$ Ksenija Dumičić ${ }^{1}$ and Petra Šprajaček ${ }^{2}$ \\ ${ }^{1}$ Faculty of Economics and Business, University of Zagreb \\ Trg J. F. Kennedy 6, 10000 Zagreb, Croatia \\ E-mail: 〈\{ipalic, kdumicic\}@efzg.hr〉 \\ ${ }^{2}$ Kauzlarićev prilaz 9, 10000 Zagreb, Croatia \\ E-mail: 〈petra.sprajacek@yahoo.com〉
}

\begin{abstract}
The purpose of the paper is to analyze misalignment of the real exchange rate in Croatia. The misalignment analysis is conducted using the permanent equilibrium exchange rate approach. The equilibrium real exchange rate is computed using the cointegration approach whereby the real exchange rate and its fundamentals, namely terms of trade, net foreign assets and the ratio of prices of tradables to non-tradables are included in cointegration analysis. The Hodrick and Prescott filter is used to obtain permanent values of the equilibrium real exchange rate. The real exchange rate misalignment is computed as the deviation of the RER from its permanent equilibrium level. Four overvaluation periods and three undervaluation periods are recorded in Croatia in the observed period. Overvaluation periods are more often and of longer duration than undervaluation periods. However, the real exchange rate does not deviate largely from its estimated equilibrium value in the observed period, and it is neither overvalued nor undervalued constantly, but the periods alternate. Considering the results of the analysis, together with the empirical characteristics of Croatian economy, namely the high foreign currency indebtedness, highly euroized economy and underdeveloped export oriented sector, the depreciation of the real exchange rate is not recommended to economic policy makers and the current Croatian exchange rate policy is appropriate.
\end{abstract}

Key words: cointegration approach, exchange rate equilibrium, currency misalignment, adjustment speed, Hodrick-Prescott filtering

Received: October 10, 2014; accepted: November 24, 2014; available online: December 30, 2014

\section{Introduction}

Equilibrium real exchange rate (ERER) is one of the most important concepts in open economy macroeconomics as its determination is crucial for computing a degree of misalignment. Economic policy makers and researchers are interested

${ }^{*}$ Corresponding author. 
in predicting and monitoring misalignment in the foreign exchange market, because in many cases it is closely related to possible current account problems or currency crises [26]. Moreover, a significant and persistent deviation of the real exchange rate (RER) from its equilibrium level, e.g., RER misalignment could have important implications on the balance of the economy. The research of [2] shows that both real overvaluation and undervaluation could have a negative impact on economic growth. On the one hand, real overvaluation could have a negative impact on export; it causes current account deficits and leads to currency crises [13], while real undervaluation could cause inflation and lead to overheating of an economy [20]. The research of [28] shows that real undervaluation can boost economic growth, thus being a key variable in promoting economic activity, especially in developing countries. Although there is a vast theoretical and empirical literature in that area, there is no consensus for measuring the degree of misalignment as it involves measuring an unobservable variable, i.e., the ERER [10].

Regarding Croatia, there has been an extensive debate about the adequacy of the exchange rate (ER) level since the implementation of the Stabilization Program in October 1993 by the Croatian government. Furthermore, taking into account the characteristics of the Croatian economy, such as a highly euroized financial system, a high degree of openness and high level of the external debt, then the determination of the appropriate level of the ER becomes more important. The Croatian National Bank maintains stability of the exchange rate of the Croatian kuna to euro in order to meet its primary objective of maintaining price stability. However, this approach has been criticized and the overvaluation of the Croatian kuna is often discussed as it is believed that the overvalued local currency could have a negative impact on the economic activity, primarily through its unfavorable effect on the competitiveness of domestic products on the global market [27].

The aim of this paper is to identify the periods of RER misalignments in Croatia in a period from the first quarter of 1998 to the first quarter of 2014. The empirical analysis is conducted in three steps. Firstly, the behavioral equilibrium exchange rate (BEER) approach is implemented in order to determine which economic fundamentals explain the dynamics of the RER in Croatia. After the selection of appropriate fundamentals, a long-run relationship between the RER and its determinants is obtained using Johansen's cointegration approach. Furthermore, the permanent equilibrium exchange rate (PEER) approach is used to determine the ERER level in Croatia, which is finally used for the calculation of misalignment and the identification of overvaluation and undervaluation periods. 


\section{Literature review}

\subsection{The main approaches for the determination of the ERER}

RER misalignments are measured as a deviation of the actual RER with respect to some equilibrium level [2]. However, there is no general agreement on the right model which should be used for the determination of the ERER, which makes its measurement even more controversial. However, based on the extensive theoretical and empirical literature (for a detailed literature review, see e.g. [15]) the following two approaches have been widely used for the determination of the equilibrium real exchange rate (ERER): the fundamental equilibrium exchange rate (FEER) and the behavioral equilibrium exchange rate (BEER). The FEER approach measures the ERER as the one that is in line with both internal and external equilibrium [30]. However, although the FEER approach is openly normative methodology, which is one of its main advantages, it relies on price elasticities that are difficult to estimate, and on current account targets that should be reached [5]. The BEER approach defines the ERER as the one that is consistent with economic fundamentals, such as net foreign asset, terms of trade, productivity and oil prices, in long run [7].

However, in [10], it is claimed that economic fundamentals identified by the BEER approach are not necessary at their equilibrium level what results in an incorrect estimation of RER misalignment. In other words, it is assumed that the actual value of economic fundamentals consists of a transitory and a permanent component, which are decomposed in order to obtain permanent levels of fundamentals [9]. Thus, the permanent component is obtained by removing the cyclical component from the estimated BEER and results in the permanent equilibrium exchange (PEER) level.

\subsection{Existing equilibrium real exchange rate models for Croatia}

Despite the fact that the ER is an important macroeconomic variable, the empirical research on RER misalignment in Croatia is limited. To the best of authors' knowledge, the econometrical assessment of the ERER was done in [4] and [6]. In both papers the BEER approach is applied in order to calculate the equilibrium real effective exchange rate of Croatian kuna and the extent to which the RER deviates from its permanent equilibrium level. For that purpose, Johansen's Maximum Likelihood method of cointegration is used. The research of [4] uses quarterly data from the first quarter of 1995 to the third quarter of 2006 on the following fundamentals: relative effective price of tradables and non- 
tradables (TNT), net foreign assets (NFA), real interest rate differential (IRD) and relative terms of trade (TOT). The results of [4] indicated that the behavior of the ERER in Croatia can be explained by TNT, IRD and TOT, while NFA showed no significance. Furthermore, the estimated model indicated that the RER was very close to the ERER in all analyzed periods. However, the only period in which the systematic deviation was longer than 2 periods was in 2000, when the RER seemed to be slightly undervalued compared to the ERER.

Furthermore, the Consultative Group on Exchange Rate Issues (CGER) of the International monetary fund (IMF) provides ER assessments for Croatia, usually once a year, as part of Article IV Staff Reports [23]. They use three different approaches, which are explained in detail in [23]: the macroeconomic balance approach, a reduced form ERER approach and the external sustainability approach in order to provide information about medium-term real exchange rates and current account balances, as well as to determine the relative importance of a number of economic factors on the aforementioned variables. The IMF estimated misalignment of the Croatian RER in 2013, whose results are presented in Table 1 . The negative values of misalignment point to overvaluation while the positive values point to undervaluation.

\begin{tabular}{|c|c|c|c|}
\hline \multicolumn{3}{|r|}{ Methodology } & $\begin{array}{c}\text { Estimated } \\
\text { misalignment }(\%)\end{array}$ \\
\hline 1. & \multicolumn{2}{|c|}{ Macroeconomic balance approach } & -0.7 \\
\hline 2 . & \multicolumn{2}{|c|}{ External sustainability approach } & \\
\hline & A. & Stabilizing NFA at $-40 \%$ of GDP & 0.2 \\
\hline & B. & Stabilizing NFA at $-89 \%$ of GDP & -6.9 \\
\hline 3. & \multicolumn{2}{|c|}{ Equilibrium exchange rate approach } & from -3.1 to 9.4 \\
\hline
\end{tabular}

Table 1: Estimated misalignment of Croatian RER in 2013 according to [24]

Table 1 shows that estimated misalignment does not provide a clear result. According to the macroeconomic balance approach, the kuna is overvalued by $0.7 \%$. On the other hand, external sustainability and the ERER approach provide mixed results, from which it cannot be concluded whether the Croatian kuna is overvalued or undervalued. 


\section{Empirical analysis of real exchange rate misalignment in Croatia}

\subsection{Estimation of the equilibrium relation between the real exchange rate and selected fundamentals}

In this paper, RER misalignment is estimated as a deviation of the RER of the Croatian kuna to euro from its PEER level. The bilateral RER of the Croatian kuna to euro is given by:

$$
\mathrm{RER}=\mathrm{NER} \times\left(\frac{\mathrm{P}^{*}}{\mathrm{P}}\right)
$$

where $N E R$ is the nominal exchange rate defined in terms of domestic currency per foreign currency, $P^{*}$ is the foreign (i.e., euro area) price level, and $P$ is the domestic price level. The data on nominal exchange rate are available at [8] and harmonized indices of consumer prices (HICP) are available at [17].

Identification of RER misalignment consists of three steps. Firstly, in order to explain the behaviour of the RER in Croatia, Johansen's approach is applied to test the cointegration between the RER and the following variables selected in line with the relevant previous empirical research: terms of trade (TOT), net foreign assets (NFA) and the ratio of prices of tradables to non-tradables $(\mathrm{TNT})^{\dagger}$. In line with [29], the value of TOT is calculated as the ratio of the deflator of the nominal value of total exports and the deflator of the nominal value of imports of goods and services. In other words, the export deflator is calculated as the ratio of the nominal value of exports and the value of exports at constant prices of the previous year, with the reference year 2005. The import deflator is calculated accordingly. The source of nominal values of exports and imports, as well as of previously mentioned real values, is [18]. The data on NFA refer to data from Croatian monetary authorities' accounts. In line with [4], NFA of the monetary sector are used to approximate the NFA of the whole economy. The TNT is calculated as the ratio of producer price indices and consumer prices indices which are available at [8]. The reference year for all indices is 2005 .

Data on price indices are available from the first quarter of 1998 onwards, what determines the sample period. Therefore, the quarterly data from the first quarter of 1998 to the first quarter of 2014 is used in cointegration analysis. The

\footnotetext{
${ }^{\dagger}$ The following variables were also tested as possible fundamentals: government consumption as a share of GDP, investment as a share of GDP, a degree of trade openness and productivity; however, they were either not significant or the vector error correction modeling assumptions were not satisfied.
} 
logarithmic transformation was conducted prior to the analysis of the presence of the seasonal component for all observed time series. The seasonal component presence is noticed in all selected time series ${ }^{\ddagger}$ and variables are seasonally adjusted. Seasonal adjustment is conducted using the TRAMO-SEATS quarterly seasonal adjustment method developed by [19].

Therefore, the seasonally adjusted logarithmic values of the three aforementioned variables are included in cointegration analysis. In order to test the stationarity of the selected time series, the Augmented Dickey-Fuller (ADF) unit root test is conducted. All selected variables are shown to be integrated of order $1, \mathrm{I}(1)$ at $1 \%$ significance $^{\S}$. Therefore, a cointegration test among variables is conducted and the vector error correction model (ECM) is estimated in order to assess the long-run relationship among variables. The estimation of the cointegration equation with all possible fundamentals, as well as with various combinations of fundamentals, has shown that either the residual autocorrelation problem is present, or the error correction term (ECT) was positive and/or insignificant ${ }^{* *}$. In order to have the RER stabilized after getting out of the equilibrium, the value of ECT should be negative.

Prior to the estimation of ECM it is required to select the proper model regarding the existence of deterministic components (trend and constant). The lowest value of Schwarz Criteria equal to -20.358 is found for the model in which constant and trend exist neither in vector ECM nor in the cointegrating equation, and for the model in which constant is present only in the cointegrating equation. Akaike Information Criteria is lowest for the model in which constant and quadratic trend are present both in VECM and in the cointegrating equation. However, calculated average values of first differences of time series used to estimate ECM are close to zero, what implies that trend is not present in the observed data. The model in which constant exists only in a long-run model (the cointegrating equation), but not in the short-run model, is selected for the analysis. The selected model points to the fact that variables integrated of order one cointegrate around the constant [12]. After the determination of the model, the number of cointegration relations is examined using the trace test and the maximum eigenvalue test. The results of both tests are presented in Table 2 showing that cointegration among selected variables exists at $5 \%$ significance.

\footnotetext{
Line and seasonal graphs are available upon request.

${ }^{\S}$ The results of the ADF test conducted in EViews 8 software are available upon request.

${ }^{* *}$ The results of cointegration analysis conducted with various variables are available upon request.
} 


\begin{tabular}{|c|c|c|c|c|c|}
\hline $\begin{array}{c}\text { Hypothesized } \\
\text { number of } \\
\text { cointegrating } \\
\text { equations }\end{array}$ & Eigenvalue & $\begin{array}{c}\text { Trace } \\
\text { statistic }\end{array}$ & $\begin{array}{c}0.05 \\
\text { Critical } \\
\text { value (trace } \\
\text { statistic) }\end{array}$ & $\begin{array}{c}\text { Maximum } \\
\text { eigenvalue } \\
\text { statistic }\end{array}$ & $\begin{array}{c}0.05 \text { Critical } \\
\text { value } \\
\text { (maximum } \\
\text { eigenvalue } \\
\text { statistic) }\end{array}$ \\
\hline 0 & 0.3350 & 55.6646 & $54.0790^{*}$ & 24.8887 & $28.5881^{*}$ \\
\hline 1 & 0.2411 & 30.7759 & 35.1928 & 16.8326 & 22.2996 \\
\hline 2 & 0.1386 & 13.9433 & 20.2618 & 9.1024 & 15.8921 \\
\hline 3 & 0.0763 & 4.8409 & 9.1645 & 4.8409 & 9.1645 \\
\hline
\end{tabular}

* denotes rejection of the null hypothesis at $5 \%$ significance

Table 2: The results of the trace test and the maximum eigenvalue test

The cointegrating relation, i.e., the long-run equation is given by:

$$
\mathrm{ERER}=\psi_{0}+\psi_{1} \mathrm{TOT}+\psi_{2} \mathrm{NFA}+\psi_{3} \mathrm{TNT},
$$

where $\psi_{0, \ldots,} \psi_{3}$ represent the coefficients of the cointegrating equation. The values of estimated coefficients with corresponding $t$-statistics and standard errors are shown in Table 3. Therefore, in the long run, all selected variables are significant in explaining the RER. Regarding the sign of TOT, an increase in prices of exported goods is assumed to generate a substitution effect which leads to appreciation, and the income effect, which causes depreciation of domestic currency. In Croatia, the impact is shown to be negative, what is in line with the substitution effect (see, for example, [25]). The expected sign of NFA according to economic theory is positive, since higher net foreign liabilities causes an increase in interest payments which have to be paid by improving trade balance. Thus competitiveness needs to be improved by RER depreciation [22]. However, in Croatia, improvement of competitiveness by means of depreciation of the real exchange rate is questionable [11], what is a possible explanation for the negative sign of NFA. The sign of TNT is in line with the previous research, since it is expected to be positive [7].

\begin{tabular}{|c|c|c|c|}
\hline Coefficient & Value & $t$-statistics & $\begin{array}{c}\text { Standard } \\
\text { error }\end{array}$ \\
\hline$\Psi_{0}$ & -2.4864 & -2.6333 & 0.9442 \\
\hline$\psi_{1}$ & -1.2398 & -9.6852 & 0.1280 \\
\hline$\psi_{2}$ & -0.0931 & -3.9980 & 0.0233 \\
\hline$\Psi_{3}$ & 1.2133 & 5.2704 & 0.2302 \\
\hline
\end{tabular}

Table 3: Cointegration equation parameters with corresponding t-statistics and standard errors 
The ECT is equal to -0.1131, whereby corresponding t-statistics equals 2.0055. The negative sign of ECT indicates that variables return to equilibrium, while its value provides information about the adjustment speed, what refers to the fact that $11.31 \%$ of disequilibrium is corrected in each quarter and the RER returns to the equilibrium level for approximately 9 quarters. Regarding the diagnostics of model residuals, White heteroskedasticity test is conducted. The White test chi-square test statistic equals 251.4268 , with the corresponding pvalue of 0.6371 , what indicates that the null hypothesis of homoscedasticity cannot be rejected at any reasonable significance level. Concerning the residual autocorrelation test, the LM test is conducted. The null hypothesis of no autocorrelation of residuals cannot be rejected up to lag length $\mathrm{k}=20$ at a $5 \%$ significance level, since all corresponding empirical significance levels are higher than 0.05. Regarding the stability of the VEC model, the estimated VEC with $r$ cointegrating relations is stable if k-r roots are equal to unity and the remaining roots have modulus less than one and lie inside the unit circle, where $\mathrm{k}$ is the number of endogenous variables and $r$ is the number of cointegrating relations. Stability of the model is checked by calculating the inverse roots of the characteristic AR polynomial using EViews ${ }^{\dagger+}$. The analysis has shown that VEC specification imposes 3 unit roots and the remaining roots have modulus less than one. Since there are four variables and one cointegrating relation, the existence of three unit roots shows that the system is stable. Therefore, the ECM diagnostic tests show that the estimated model is appropriate. For a detailed explanation of problems of heteroskedasticity, autocorrelation as well as AR roots calculation see, for example, [16].

After the estimation of the long-run equation, the ERER is estimated by applying the long-run coefficients to the actual values of macroeconomic fundamentals to achieve a long-run equilibrium value for the RER. However, in [10], it is stated that macroeconomic fundamentals included in the long-run equation are not necessary at their equilibrium level since they fluctuate around the equilibrium. Therefore, in order to obtain the permanent values of the ERER, the Hodrick and Prescott filter (HP filter) is used [21]. In line with [1], [3] and [7], the PEER is obtained using the estimated cointegration parameters and feeding the model with permanent components of fundamentals. The permanent components of selected fundamentals are estimated using the HP filter and characterized as sustainable levels which are therefore consistent with the concept of equilibrium [1].

The values of the RER, the ERER and the PEER are shown in Figure 1. As expected, the PEER which presents the HP-filtered trend component of the ERER, exhibits less volatility than the ERER. The high positive correlation

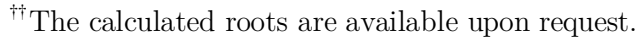


between the ERER and the PEER with the coefficient of correlation equal to 0.87 indicates that the ERER and the PEER are closely positively correlated. Figure 1 shows that the RER does not deviate largely from the equilibrium value of the ER, measured either by the ERER or the PEER. RER misalignment is discussed below in detail.

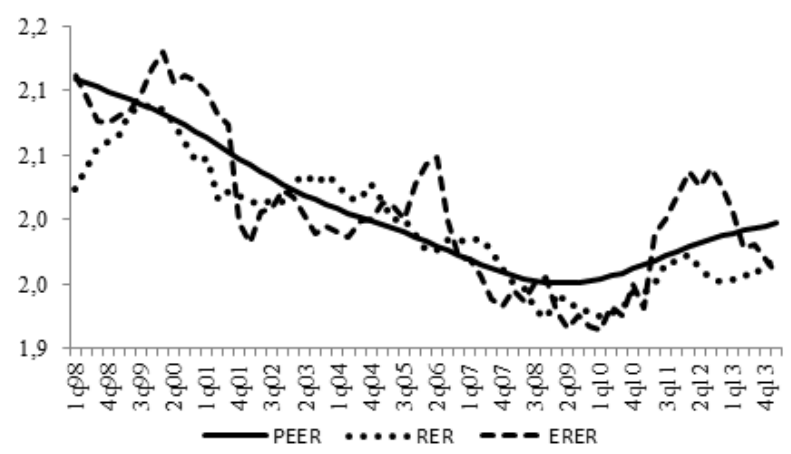

Figure 1: The $R E R$, the E'RE'R and the PE'E'R in C'roatia from the first quarter of 1998 to the first quarter of 2014

\subsection{Estimation of exchange rate misalignment}

After the estimation of the long-run relationship between the RER and selected macroeconomic fundamentals and using the HP filter to obtain the permanent values, it is necessary to determine RER misalignment. RER misalignment is defined as the deviation of the RER from its permanent equilibrium level [3]:

$$
M I S=\left(\frac{R E R-P E E R}{P E E R}\right) \times 100 .
$$

Figure 2 shows the calculated values of the RER misalignment in Croatia, which are further summarized in Table 4.

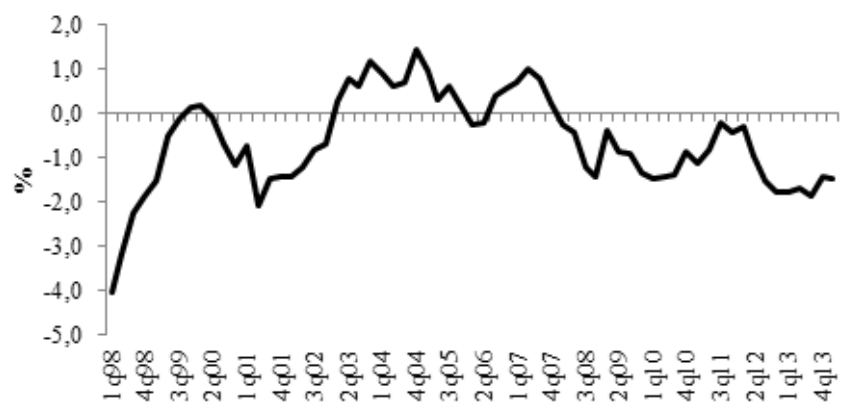

Figure 2: RER misalignment in Croatia from the first quarter of 1998 to the first quarter of 2014 
Maximum misalignment refers to overvaluation periods in the first quarter of 1998 and in the second quarter of 2001. The highest undervaluation episode occurred in the fourth quarter of 2004.

According to [14], an ER is considered undervalued when it is depreciated more than the ERER and overvalued when it is appreciated more than the ERER. Overvaluation refers to negative RER misalignment whereby RER is lower than the PEER, while undervaluation is defined as positive RER misalignment whereby the RER is higher than the PEER. Table 4 shows the summary of episodes of RER misalignment in Croatia. The four overvaluation periods and three undervaluation periods are recorded. The examination of RER misalignment measured by the PEER has shown that in 45 out of 65 quarters observed the RER of the Croatian kuna to euro was overvalued, while in 20 observed quarters it was undervalued.

\begin{tabular}{|c|l|c|c|c|}
\hline Period & \multicolumn{1}{|c|}{ Outcome } & $\begin{array}{c}\text { Minimum } \\
(\%)\end{array}$ & $\begin{array}{c}\text { Maximum } \\
(\%)\end{array}$ & $\begin{array}{c}\text { Average } \\
(\%)\end{array}$ \\
\hline 1998Q1-1999Q3 & Overvaluation & -4.054 & -0.122 & -1.932 \\
\hline 1999Q4-2000Q1 & Undervaluation & 0.166 & 0.110 & 0.138 \\
\hline 2000Q2-2004Q2 & Overvaluation & -2.101 & -0.100 & -1.081 \\
\hline 2003Q1-2005Q4 & Undervaluation & 0.149 & 1.438 & 0.702 \\
\hline 2006Q1-2006Q2 & Overvaluation & -0.281 & -0.225 & -0.253 \\
\hline 2006Q3-2007Q4 & Undervaluation & 0.206 & 0.993 & 0.599 \\
\hline 2008Q1-2014Q1 & Overvaluation & -1.895 & -0.217 & -1.102 \\
\hline
\end{tabular}

Table 4: Episodes of RER misalignment in Croatia

Intitially, this result may suggest that depreciation is necessary due to more frequent overvaluation episodes. However, it should be emphasized that exchange rate misalignment is in the relatively narrow interval from $-4.054 \%$ in the first quarter of 1998 to $1.438 \%$ in the fourth quarter of 2004 . Exchange rate misalignment was at its highest in the periods close to banking crises of 1999 and 2002 as well as when global financial crises spilled over to the Croatian economy in 2008. In the aforementioned periods the calculated misalignment has shown overvaluation of the Croatian kuna to euro. The fact that overvaluation was higher and more frequent in the observed period than undervaluation is still not a sufficient reason to recommend depreciation in Croatia. The exchange rate is neither overvalued nor undervalued constantly but the periods alternate. Moreover, the range of misalignment in the observed period is relatively narrow. Regarding depreciation of the real exchange rate, [11] have shown that depreciation in Croatia might affect export positively, but alongside with that external debt would increase. When discussing the implications of the conducted 
analysis for economic policy, the characteristics of the Croatian economy should be considered. Due to high euroization and indebtedness of all sectors of the economy in a foreign currency (mainly euro), real exchange rate depreciation could increase in foreign currency debt. The negative impact of depreciation through the negative effect on wealth may outweigh the positive impact of depreciation through the competitiveness effect. Moreover, due to the fact that Croatian imports continually exceed exports, as well as considering an underdeveloped export oriented sector in Croatia, the impact of depreciation on competitiveness is rather limited. Therefore, taking into consideration the current economic situation, exchange rate depreciation is not recommended for Croatian monetary authorities, what points to the fact that the present exchange rate policy is suitable.

\section{Conclusion}

The conducted research has shown an analysis of real exchange rate misalignment in case of a small open economy. There has been an extensive debate about the adequacy of the exchange rate level in Croatia since the implementation of the Stabilization Program in October 1993 by the Croatian government. The question whether the Croatian kuna is overvalued is one of the dominant issues related to conducting monetary policy in Croatia. While monetary authorities maintain stability of the exchange rate in Croatia in order to preserve price stability, the overvalued local currency could have an unfavorable effect on the competitiveness of domestic products on the global market. Measuring overvaluation or undervaluation of the exchange rate is quite a controversial task for economic analysts from the methodological point of view. Accordingly, the purpose of this paper is to determine whether the real exchange rate in Croatia is misaligned. In order to assess exchange rate misalignment in Croatia, the permanent equilibrium exchange rate (PEER) approach is applied. The equilibrium real exchange rate is estimated by Johansen's cointegration approach, whereby the real exchange rate and three macroeconomic fundamentals, namely terms of trade net foreign assets and ratio of prices of tradables to non-tradables, are included in the error correction model. Moreover, after the equilibrium real exchange rate is obtained from the error correction model, the permanent values of the real exchange rate are estimated by extracting the trend component from the equilibrium real exchange rate. Real exchange rate misalignment is computed as a deviation of the observed real exchange rate from its permanent equilibrium level. Overvaluation refers to negative misalignment whereby the real exchange rate is lower than its permanent equilibrium value, positive misalignment refers to undervaluation. Four overvaluation periods and three undervaluation periods 
are recorded in Croatia in the observed period. In the observed period, overvaluations are more frequent and longer lasting than undervaluations, what might point to the need of depreciation of the exchange rate in Croatia. However, regarding the foreign exchange policy recommendations implied by the conducted analysis, depreciation is not recommended due to the following reasons. Firstly, periods of overvaluation and undervaluation alternate and overvaluation is not constant. Secondly, the real exchange rate does not deviate largely from its estimated equilibrium value. The third reason is related to the structure of the Croatian economy. Due to high euroization and indebtedness of all sectors of the economy in a foreign currency (mainly euro), real exchange rate depreciation could cause a negative effect on the economy through the increase in foreign currency debt. Moreover, due to the fact that imports continually exceed exports, as well as considering an underdeveloped export oriented sector in Croatia, the impact of depreciation on competitiveness is limited. Therefore, with respect to the results of the analysis, together with the empirical characteristics of the Croatian economy, it could be concluded that exchange rate depreciation is not recommended by the Croatian monetary authorities. Concerning the structure of the Croatian economy, the current exchange rate policy is suitable. Calculation of the equilibrium real exchange rate is very important for monetary authorities of small open economies as its determination is essential in estimation of misalignment. Significant and persistent real exchange misalignment could have important implications in small open economies. Future research in this topic will therefore be aimed at expanding the conducted analysis of real exchange rate misalignment to small open economies similar to Croatia regarding the political and economic background.

\section{Acknowledgment}

This paper has been fully supported by the Croatian Science Foundation under the project STRENGTHS No. 9402.

\section{References}

[1] Abida, Z. (2011). Real exchange rate misalignment and economic growth: An empirical study for the Maghreb countries. International Journal of Economics and Finance, 3 (3), 190-201.

[2] Aguirre, A. and Calderón, C. (2005). Real exchange rate misalignments and economic performance. Central Bank of Chile, Working Paper, No. 315. 
[3] Aliyu, S. (2011). Real exchange rate misalignment: An application of Behavioural Equilibrium Exchange Rate (BEER) to Nigeria. Central Bank of Nigeria Occasional Paper, No. 41.

[4] Belullo, A. and Broz, T. (2007). Do fundamentals explain the behaviour of the real effective exchange rate in Croatia?, Proceedings of the 28th International Conference on Organisational Science Development. Fakultet za organizacijske vede, Maribor, 109-130.

[5] Benassy-Quere, A., Duran-Vigneron, P., Lahrèche-Révil, A. and Mignon, V. (2004). Burden sharing and exchange-rate misalignments within the group of twenty. In Bergsten, C.F. and Williamson, J. (Eds). Dollar Adjustment: How Far? Against What?. Washington D.C.: Institute for International Economics.

[6] Broz, T. and Ridzak, T. (2007). Exchange rate misalignment - a case of Croatia. Global challenges for competitiveness: Business and government perspective, Sveučilište Jurja Dobrile u Puli, Odjel za ekonomiju i turizam "Dr. Mijo Mirković", 312-321.

[7] Clark, P.B. and MacDonald, R. (1998). Exchange rates and economic fundamentals - A methodological comparison of BEERs and FEERs. International Monetary Fund. Working Paper 98/67.

[8] Croatian National Bank, Statistical Survey, www.hnb.hr [Accesssed on 15 June 2014]

[9] Daboh, L. (2007). Real exchange rate misalignment in the West African monetary zone. Journal of Monetary and Economic Integration, 10 (2).

[10] Dufrenot, G. and Yehoue, E. (2005). Real exchange rate misalignment: A panel cointegration and common factor analysis. International Monetary Fund. Working Paper 05/164.

[11] Dumičić, K., Palić, I. and Šprajaček, P. (2011). Procjena učinaka konkurentnosti i bogatstva kao posljedica promjene realnog deviznog tečaja na hrvatsko gospodarstvo (Estimates on competitiveness and wealth effects as consequence of real exchange rate on Croatian economy), Zbornik Ekonomskog fakulteta u Zagrebu (Proceedings of Faculty of Economics in Zagreb), 2/2011, 35-52.

[12] Dumičić, K. and Čibarić, I. (2010). The analysis of household savings in Republic of Croatia using cointegration approach. The Business Review, Cambridge, 15(1), 220226.

[13] Easterly, W. (2005). National policies and economic growth: A reappraisal. In Aghion, P. and Durlauf, S. (Eds). Handbook of Economic Growth. Amsterdam: Elsevier.

[14] Edwards, S. (1989). Real Exchange Rates, Devaluation, and Adjustment: Exchange Rate Policy in Developing Countries. Cambridge, Massachusetts: MIT Press.

[15] Edwards, S. and Savastano, M.A. (1999). Exchange rates in emerging economies: What do we know? What do we need to know? National Bureau of Economic Research. Working Paper No. 7228.

[16] Enders, W. (2010). Applied Econometric Time Series. 3rd Ed. London: John Wiley \& Sons Inc.

[17] Eurostat, Harmonized Index of Consumer Prices, http://epp.eurostat.ec.europa.eu/portal/page/portal/hicp/data/database [Accesssed on 15 September 2014] 
[18] Eurostat, National accounts: Quarterly accounts, GDP and main componentsvolumes, http://appsso.eurostat.ec.europa.eu/ [Accesssed on 20 August 2014]

[19] Gomez, V. and Maravall, A. (1996). Programs TRAMO and SEATS: Instruction for users. Banco de Espana. Working paper No. 9628.

[20] Haddad, M. and Pancaro, C. (2010). Can real exchange rate undervaluation boost exports and growth in developing countries? Yes, but not for long. World Bank Economic Premise, No. 20, 1-5.

[21] Hodrick, R. and Prescott, E.C. (1997). Postwar U.S. business cycles: An empirical investigation. Journal of Money, Credit, and Banking, 29(1), 1-16.

[22] Hossfeld, O. (2010). Equilibrium real exchange rates and real exchange rate misalignments: time series vs. panel estimates. FIW Working paper, No. 065.

[23] International monetary fund (2006). Methodology for CGER exchange rate assessments. https://www.imf.org/external/np/pp/eng/2006/110806.pdf [Accesssed on 14 June 2014]

[24] International monetary fund (2014). IMF country report, Republic of Croatia. No. $14 / 124$.

[25] Komarek, L. and Melecky, M. (2005). The behavioural equilibrium exchange rate of the Czech koruna. Czech National Bank. Working Paper 5/2005.

[26] Musyoki, D., Pokhariyal, G.P. and Pundo, M. (2012). Real exchange rate equilibrium and misalignment in Kenya. Journal of Business Studies Quarterly, 3(4), $24-42$.

[27] Nikić, G. (2000). Kontroverze tečajne politike (Controversies of exchange rate policy), Ekonomski pregled (Economic Review), 51 (9-10), 1102-1122.

[28] Rodrik, D. (2008). The real exchange rate and economic growth. Brookings papers on economic activity. Economic Studies Program, The Brookings Institution, 39(2), $365-439$.

[29] Tomić, D. (2012). Utjecaj prihodovnih uvjeta razmjene na gospodarsku aktivnost Republike Hrvatske (Connection of terms of trade, openness and economic growth in the Republic of Croatia), Doktorska disertacija (Doctoral dissertation), Zagreb: Ekonomski fakultet (Zagreb: Faculty of Economics).

[30] Williamson, J. (1994). Estimating equilibrium exchange rates. Peterson Institute Press: Peterson Institute for International Economics, No. 17. 